Supporting information

\title{
Activatable Hybrid Polyphosphazene-AuNP Nanoprobe for ROS Detection by Bimodal PA/CT Imaging
}

Mathilde Bouché, ${ }^{\dagger}$ Manuel Pühringer, $₫$ Aitziber Iturmendi, ${ }^{\ddagger}$ Ahmad Amirshaghaghi,,${ }^{\S}$ Andrew Tsourkas, ${ }^{\S}$ Ian Teasdale, ${ }^{\ddagger}$ David P. Cormode $\dagger, \S^{*}$

$\dagger$ Department of Radiology, University of Pennsylvania, Philadelphia, Pennsylvania 19104, United States

$\$$ Institute of Polymer Chemistry, Johannes Kepler University Linz, Altenberger Straße 69, 4040, Linz, Austria

$\S$ Department of Bioengineering, School of Engineering and Applied Sciences, University of Pennsylvania, Philadelphia, Pennsylvania 19104, United States

* Corresponding author:

Dr David P. Cormode

E-mail: david.cormode@uphs.upenn.edu. Tel: 215-615-4656. Fax: 240-368-8096. 


\section{Polymer synthesis experimental details}

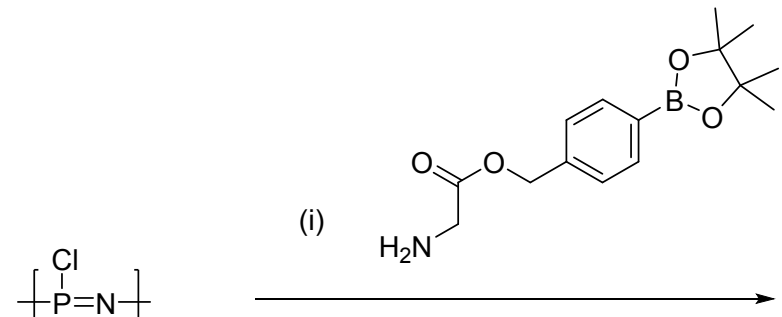

(ii)<smiles>C=CCOC(=O)CN</smiles>

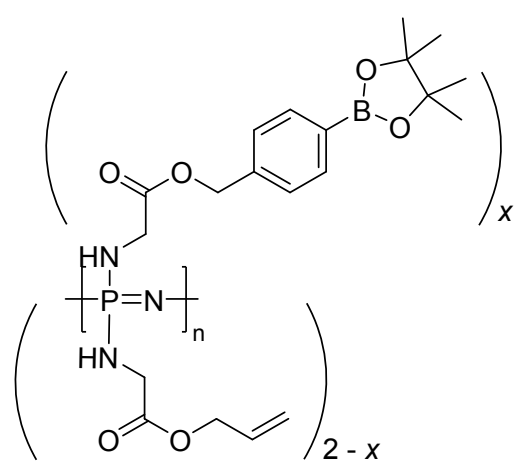

(iii)
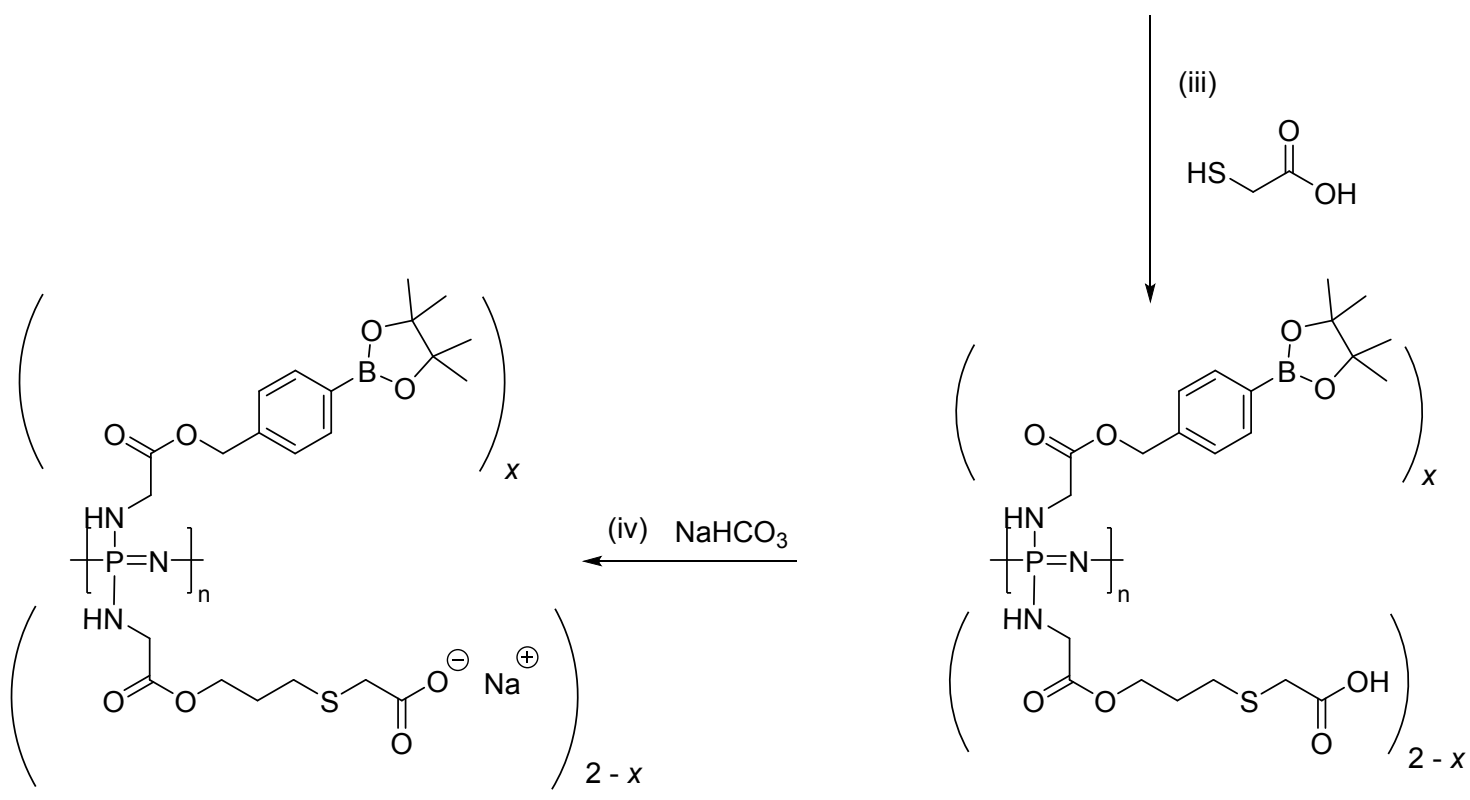

Scheme S1. Synthesis of the (arylboronate)polyphosphazene PPB in 4 steps. Reagents and conditions: (i) glycinate arylboronic acid pinacol ester, THF, Et 3 N, rt, 24h; (ii) Excess of allyl glycinate, THF, Et ${ }_{3} \mathrm{~N}, \mathrm{rt}, 24 \mathrm{~h}$; (iii) thioglycolic acid, $7 \mathrm{wt} \%$ DMPA, MeOH, $5{ }^{\circ} \mathrm{C}, 3 \mathrm{~h}$; (iv) $\mathrm{NaHCO}_{3}$ solution. $\mathrm{X} \approx 1$.

\subsection{Materials}

All synthetic procedures were carried out air-free either under nitrogen using Schlenk line techniques or under argon in a glovebox (MBRAUN). The glassware was dried in an oven at $120^{\circ} \mathrm{C}$ prior use. The monomer trichlorophosphoranimine $\left(\mathrm{Cl}_{3} \mathrm{P}=\mathrm{NSiMe}_{3}\right)$ was synthesized as 
reported previously. ${ }^{1}$ Boc-gly-arylboronic acid pinacol ester was synthesized according to previous work. ${ }^{2}$ Boc-gly-allyl was synthesized by previously reported method. ${ }^{3}$ Dichlorotriphenylphosphorane, lithium bis(trimethylsilyl)amide, phosphorus trichloride, sulfuryl chloride, allyl bromide, potassium carbonate, N,N'-dicyclohexylcarbodiimide, 4(dimethylamino)pyridine (DMAP), 2,2-dimethoxy-2-phenylacetophenone (DMPA), and thioglycolic acid were purchased from Sigma (Vienna, AT). N-(tert-Butoxycarbonyl)glycine, calcium chloride dihydrate and trimethylamine $\left(\mathrm{Et}_{3} \mathrm{~N}\right)$ were acquired from Merck, 4(Hydroxymethyl)phenylboronic acid pinacol ester from Flurorochem and trifluoroacetic acid $\left(\mathrm{CF}_{3} \mathrm{CO}_{2} \mathrm{H}\right)$ from TCI Europe. All solvents were obtained from VWR Europe. The photochemical reaction was carried out in a glass vial in a Rayonet Chamber Reactor with UV lamp from Camag centered at $254 \mathrm{~nm}$ and the solvent was purged with $\mathrm{N}_{2}$ for at least 30 min prior use.

Poly(dichloro)phosphazene (Scheme S1) was synthesized solvent-free similar to previously reported procedure. ${ }^{1}$ Dichlorotriphenylphosphorane $(4.00 \mathrm{mg}, 12.00 \mathrm{mmol}, 1 \mathrm{eq}$. was mixed with $\mathrm{Cl}_{3} \mathrm{P}=\mathrm{NSiMe}_{3}(1.50 \mathrm{~g}, 6.67 \mathrm{mmol}, 556$ eq.) and stirred for $24 \mathrm{~h}$ until a viscous solution was obtained and a single peak in the ${ }^{31} \mathrm{P}$ NMR spectroscopy at $-18.2 \mathrm{ppm}$ was observed. Meantime, boc-gly-arylboronic acid pinacol ester $(2.61 \mathrm{~g}, 6.67 \mathrm{mmol}, 1$ eq. $)$ was deprotected in $\mathrm{CF}_{3} \mathrm{CO}_{2} \mathrm{H} / \mathrm{DCM}$ (1:3) overnight at room temperature. The solvent was removed under vacuum and toluene was added three times to remove the excess of $\mathrm{CF}_{3} \mathrm{CO}_{2} \mathrm{H}$ by coevaporation. The glycinate arylboronic acid pinacol ester was obtained as a white solid and used without further purification in the post-polymerization step. In the glove box, it was redissolved in $50 \mathrm{~mL}$ anhydrous $\mathrm{THF}$ and an excess of $\mathrm{Et}_{3} \mathrm{~N}(\sim 1.5 \mathrm{~mL}, 1.6$ eq.) was added to neutralize possible $\mathrm{CF}_{3} \mathrm{CO}_{2} \mathrm{H}$ residues. Then the poly(dichloro)phosphazene (6.67 mmol, 1 eq.) solution was transferred to the previous solution and stirred at room temperature for $24 \mathrm{~h}$. Meanwhile, boc-gly-allyl was deprotected following the same procedure. Excess of boc-gly- 
allyl (2.59 g, $12.03 \mathrm{mmol}, 1.8$ eq.) was deprotected in $\mathrm{CF}_{3} \mathrm{CO}_{2} \mathrm{H} / \mathrm{DCM}$ (1:3) overnight at room temperature. The solvent was removed under vacuum and toluene was added three times to remove the excess of $\mathrm{CF}_{3} \mathrm{CO}_{2} \mathrm{H}$. The allyl glycinate was obtained as a white solid and redissolved in anhydrous THF ( $\sim 50 \mathrm{~mL})$ and excess of $\mathrm{Et}_{3} \mathrm{~N}(\sim 2 \mathrm{~mL}, 2.1$ eq.). The allyl glycinate solution was added dropwise to the partially substituted polymer and stirred at room temperature for further $24 \mathrm{~h}$. Then, the suspension was filtered to remove the insoluble triethylammonium chloride salt and the solvent was concentrated under vacuum. The polymer was purified by dialysis ( $3.5 \mathrm{kDa}$ cut-off) in $\mathrm{H}_{2} \mathrm{O}$ for $30 \mathrm{~min}$ and then in $\mathrm{EtOH}$ overnight. The solvent was then removed under vacuum to yield an orange sticky product. Yield $=1.70 \mathrm{~g}$ (63\%). ${ }^{1} \mathrm{H}$ NMR (300 MHz, $\left.\mathrm{CD}_{3} \mathrm{OD}, \delta\right): 7.67$ (br, 2H, Ar-H), 7.30 (br, 2H, Ar-H), 5.86 (br, 1H, $\left.\mathrm{CH}_{2}-\mathbf{C H}=\mathrm{CH}_{2}\right), 5.17$ (br, 4H, $\left.\mathrm{CH}_{2}-\mathrm{CH}=\mathbf{C H}_{2}, \mathbf{C O O}-\mathbf{C H}_{2}-\mathrm{Ar}\right), 4.54$ (br, 2H, OOC-CH $\mathbf{2}^{-}$ $\left.\mathrm{CH}=\mathrm{CH}_{2}\right), 3.83\left(\mathrm{br}, 4 \mathrm{H}, \mathrm{OOC}-\mathbf{C H}_{2}-\mathrm{NH}\right), 1.29$ (br, 12H, O-C-CH$)$ ppm. ${ }^{31} \mathrm{P}$ NMR $(121 \mathrm{MHz}$, $\left.\mathrm{CD}_{3} \mathrm{OD}, \delta\right): 2.10$ ppm. $\mathrm{GPC} \mathrm{M}_{\mathrm{w}}=340000, \mathrm{M}_{\mathrm{n}}=100600$

This (arylboronate)polyphosphazene polymer $(228 \mathrm{mg}, 0.51 \mathrm{mmol}, 1 \mathrm{eq}$.$) , thioglycolic acid$ (93.56 mg, $70 \mathrm{~mL}, 1.01 \mathrm{mmol}, 2$ eq. per allyl group), and DMPA (22.66 mg, $7 \mathrm{wt} \%$ ) were dissolved in $\mathrm{MeOH}$, which was purged with $\mathrm{N}_{2}$ previously for at least $30 \mathrm{~min}$. The reaction was carried out under UV light at $5^{\circ} \mathrm{C}$ for $3 \mathrm{~h}$. After the reaction, the polymer was purified by precipitation in EtOAc (to remove DMPA). Yield $=121 \mathrm{mg}(44 \%) .{ }^{1} \mathrm{H}$ NMR $(300 \mathrm{MHz}$,

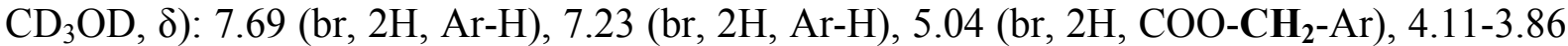
(br, 6H, COO- $\mathbf{C H}_{2}-\mathrm{CH}_{2}-\mathrm{CH}_{2}-\mathrm{S}, 2 \mathrm{x}$ OOC- $\mathbf{C H}_{2}-\mathrm{NH}$,), 3.15 (br, 2H, $\left.\mathrm{CH}_{2}-\mathrm{S}-\mathbf{C H}_{2}-\mathrm{COOH}\right), 2.65$ (br, 2H, COO- $\left.\mathrm{CH}_{2}-\mathrm{CH}_{2}-\mathbf{C H}_{2}-\mathrm{S}\right), 1.86$ (br, 2H, COO- $\mathrm{CH}_{2}-\mathbf{C H}_{2}-\mathrm{CH}_{2}-\mathrm{S}$ ), 1.28 (br, $12 \mathrm{H},(\mathrm{O}-\mathrm{C}-$ $\left.\left.\left(\mathbf{C H}_{3}\right)_{2}\right)_{2}\right) \mathrm{ppm}$ 
$121 \mathrm{mg}(0.22 \mathrm{mmol}, 1$ eq.) of the carboxylic acid functionalized polymer was suspended in $\mathrm{NaHCO}_{3}$ solution $\left(19 \mathrm{mg}, 0.22 \mathrm{mmol}\right.$, 1eq., $5 \mathrm{~mL} \mathrm{H} \mathrm{H}_{2} \mathrm{O}$ ). The suspension was rigorously stirred until its total dissolution and then the polymer was lyophilised. Yield = quantitative. ${ }^{1} \mathrm{H}$ NMR (300 MHz, $\mathrm{D}_{2} \mathrm{O}, \delta$ ): 7.62 (br, 2H, Ar-H), 7.14 (br, 2H, Ar-H), 4.93 (br ${ }^{* a}$, COO-CH$-\mathbf{C r}$ ), 3.993.60 (br, $6 \mathrm{H}, \mathrm{COO}-\mathbf{C H}_{2}-\mathrm{CH}_{2}-\mathrm{CH}_{2}-\mathrm{S}, 2 \mathrm{x}$ OOC- $\mathbf{C H}_{2}-\mathrm{NH}$,), 3.09 (br, 2H, $\mathrm{CH}_{2}-\mathrm{S}_{-} \mathbf{C H}_{2}-\mathrm{COOH}$ ), 2.43 (br, 2H, COO- $\left.\mathrm{CH}_{2}-\mathrm{CH}_{2}-\mathbf{C H}_{2}-\mathrm{S}\right), 1.72$ (br, 2H, COO- $\left.\mathrm{CH}_{2}-\mathbf{C H}_{2}-\mathrm{CH}_{2}-\mathrm{S}\right), 1.18$ (br, $1 \mathrm{H}^{*}$,,$(\mathrm{O}$ $\left.\left.\mathrm{C}-\left(\mathbf{C H}_{3}\right)_{2}\right)_{2}\right)$ ppm. ${ }^{31} \mathrm{P}$ NMR $\left(121 \mathrm{MHz}, \mathrm{D}_{2} \mathrm{O}, \delta\right): 2.60$ ppm. ${ }^{* a}$ Due to the overlapping of the $\mathrm{D}_{2} \mathrm{O}$ signal with this region, there is some uncertainty in the integration. For this reason, it has been measured also in $\mathrm{CD}_{3} \mathrm{OD} .{ }^{1} \mathrm{H}$ NMR $\left(300 \mathrm{MHz}, \mathrm{CD}_{3} \mathrm{OD}, \delta\right): 7.64$ (br, 2H, Ar-H), 7.29 (br, 2H, Ar-H), 5.10 (br, 2H, COO- $\left.\mathbf{C H}_{2}-\mathrm{Ar}\right), 4.14-3.81$ (br, 6H, COO- $\mathbf{C H}_{2}-\mathrm{CH}_{2}-\mathrm{CH}_{2}-\mathrm{S}, 2 \mathrm{x}$ OOC$\mathbf{C H}_{2}-\mathrm{NH}$,), 3.13 (br, 2H, CH $2-\mathrm{S}-\mathbf{C H}_{2}-\mathrm{COOH}$ ), 2.60 (br, 2H, COO- $\mathrm{CH}_{2}-\mathrm{CH}_{2}-\mathbf{C H}_{2}-\mathrm{S}$ ), 1.86 (br, 2H, COO-CH$\left.{ }_{2}-\mathbf{C H}_{2}-\mathrm{CH}_{2}-\mathrm{S}\right), 1.29\left(\mathrm{br}, 1 \mathrm{H}^{* \mathrm{~b}},\left(\mathrm{O} \mathrm{C}-\left(\mathbf{C H}_{3}\right)_{2}\right)_{2}\right)$ ppm. ${ }^{31} \mathrm{P} \mathrm{NMR}(121 \mathrm{MHz}$, $\mathrm{CD}_{3} \mathrm{OD}, \delta$ ): $2.29 \mathrm{ppm} .{ }^{* b}$ Due to the hydrolysis of the boronic acid ester in water to cleave the pinacol group. 
2. Physico-chemical characterization of PPB NP and PCPP NP
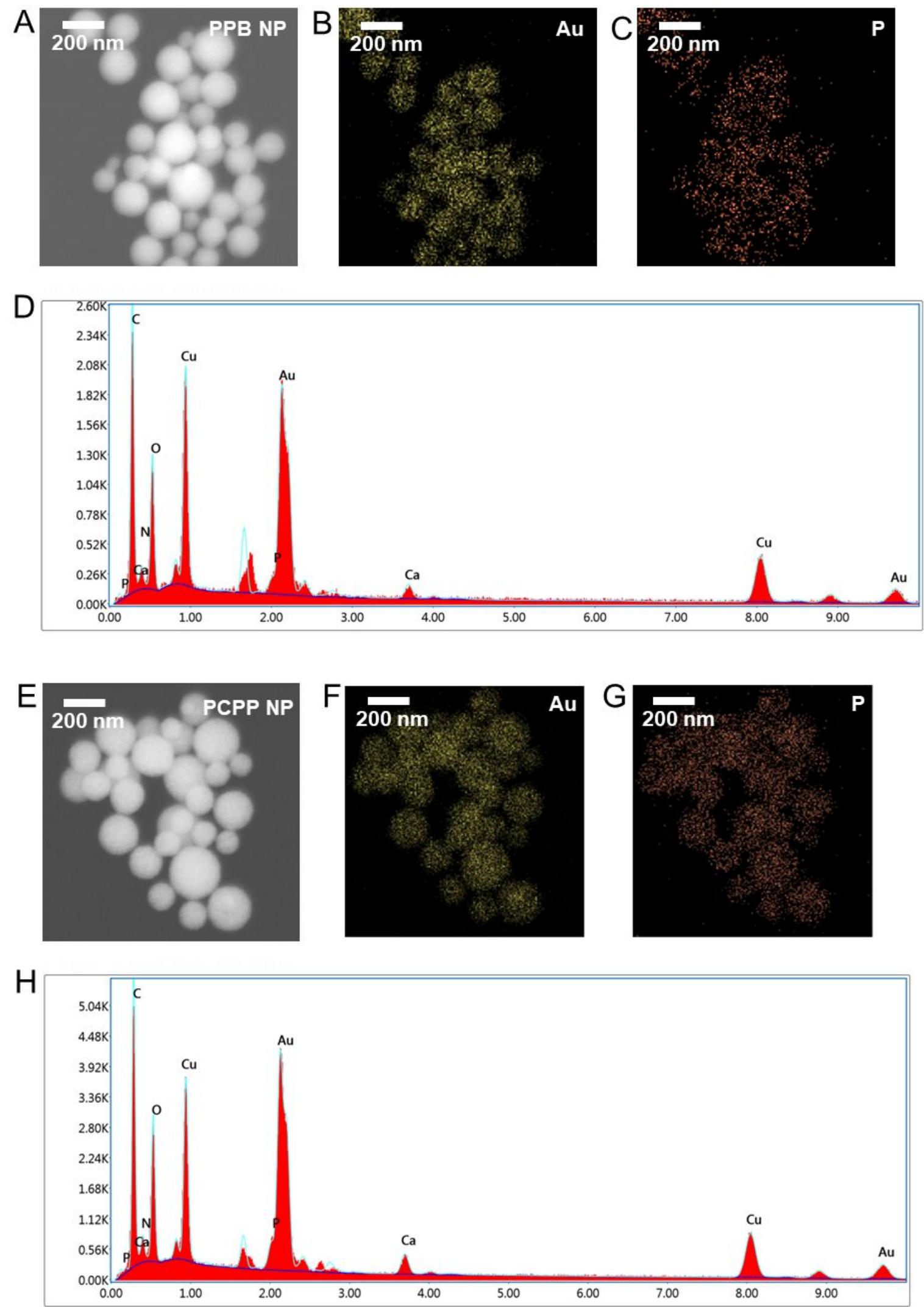
Figure S1. Characterization of PPB NP by A) SEM, B-C) elemental mapping of Au (green) and P (orange) respectively, D) EDX. Characterization of PCPP NP by E) SEM, F-G) elemental mapping of $\mathrm{Au}$ (green) and P (orange) respectively, H) EDX.

\section{Degradability of PPB NP by ROS species}

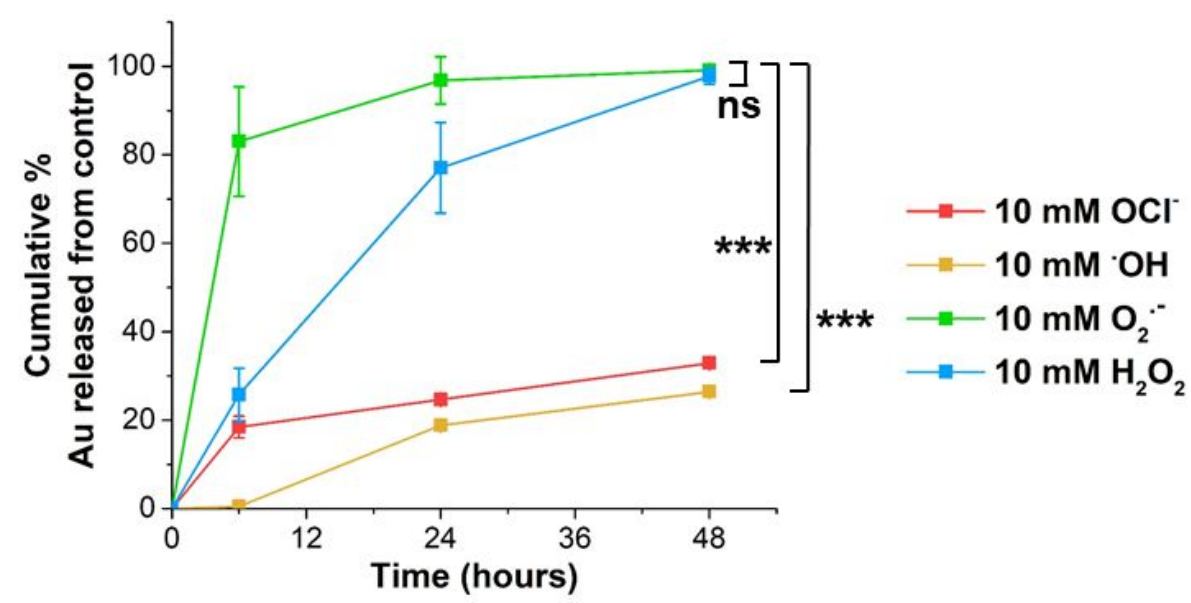

Figure S2. Effect of different ROS species of PPB NP degradation determined by cumulative gold released. $* * *$ and ' $n s$ ' indicate either a statistically significant difference at $\mathrm{p}<0.001$ or non-statistically significant differences, respectively. 


\section{Contrast enhancement in $\mathrm{CT}$ and PA imaging}
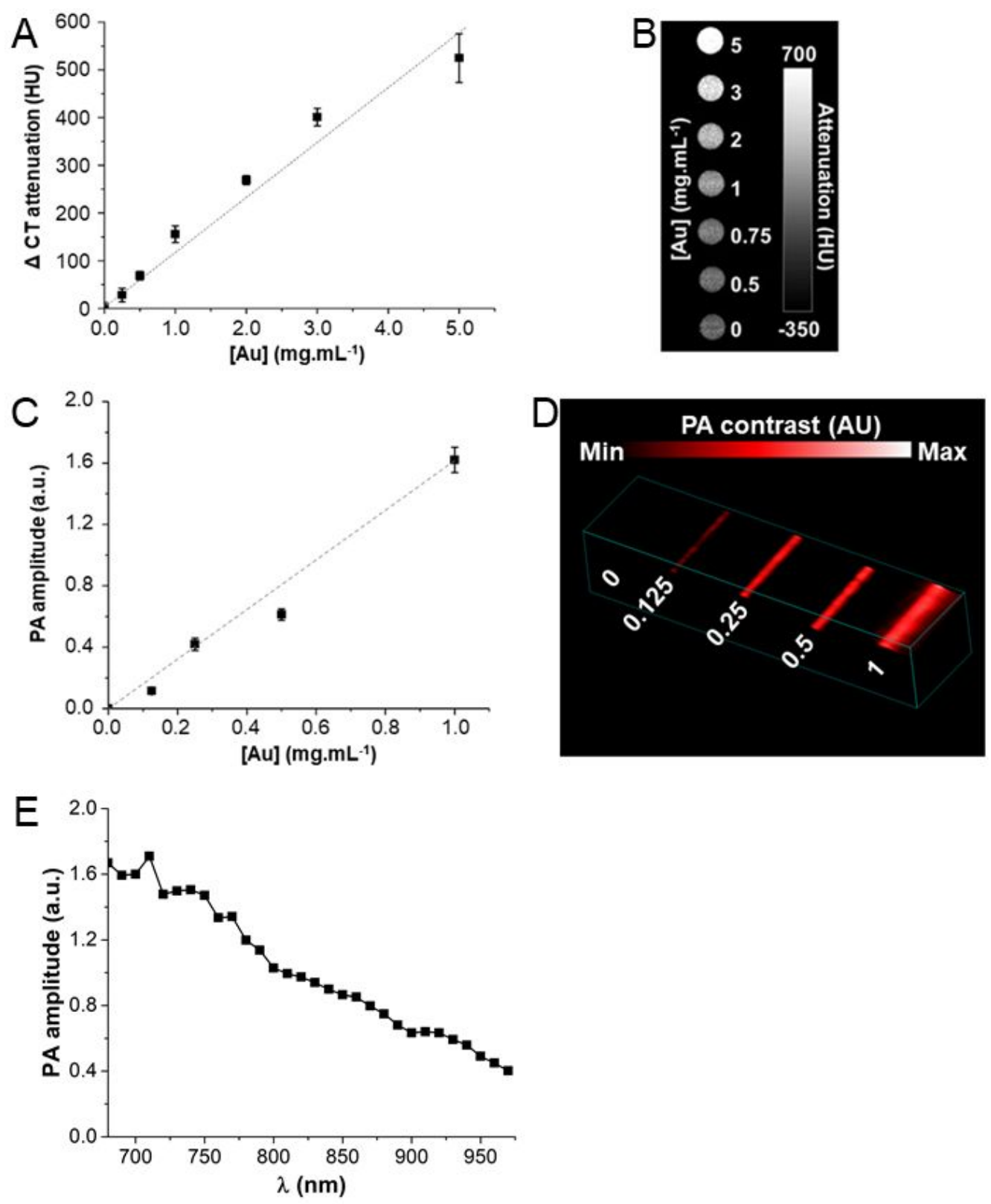

Figure S3. Contrast enhancement provided by the ROS sensitive nanoparticles at various gold concentrations in A-B) CT and C-D) PA imaging. E) PA signal at laser wavelengths from 680 to $970 \mathrm{~nm}$. 
5. $\mathrm{H}_{2} \mathrm{O}_{2}$ dose response of $\mathrm{PPB} \mathrm{NP}$
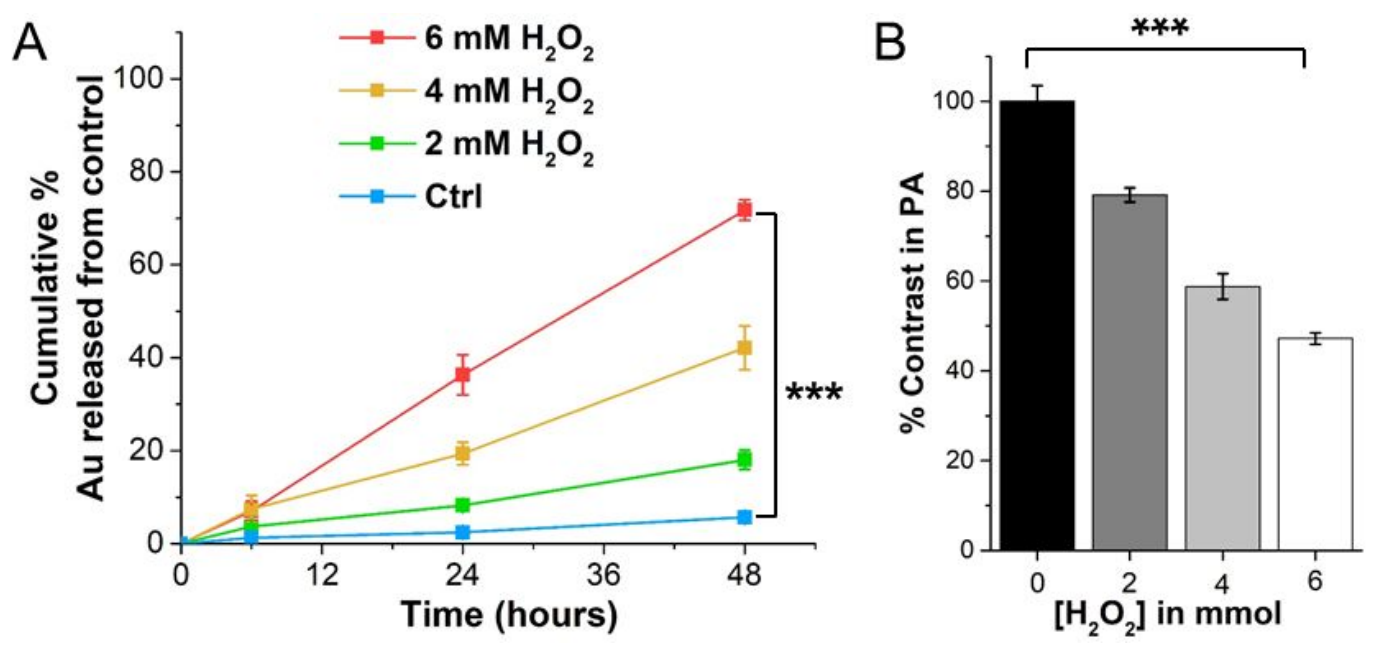

Figure S4. A) Cumulative gold released determined by ICP-OES showing the $\mathrm{H}_{2} \mathrm{O}_{2}$ dose dependent degradation of PPB NP. B) Percentage of contrast in PA depending on the dose of $\mathrm{H}_{2} \mathrm{O}_{2}$. Experiments done at a gold concentration of $1 \mathrm{mg} \cdot \mathrm{mL}^{-1}$. $* * *$ indicates a statistically significant difference at $\mathrm{p}<0.001$.

\section{Effect of PPB NP on cell viability}

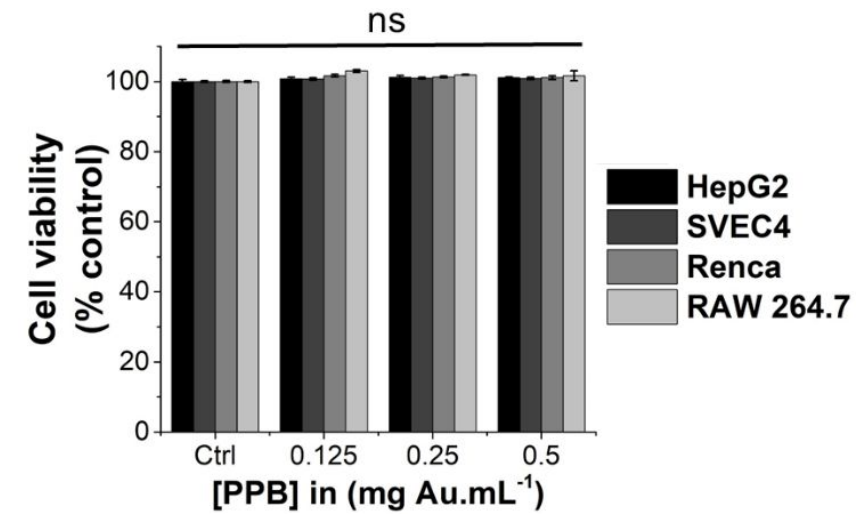

Figure S5. Viability of 4 cell lines incubated for 8 hours with the nanoparticles suspended in cell medium, determined by LIVE-DEAD assay. 'ns' indicates non-statistically significant differences. 


\section{ROS and TNF- $\alpha$ production in macrophages}
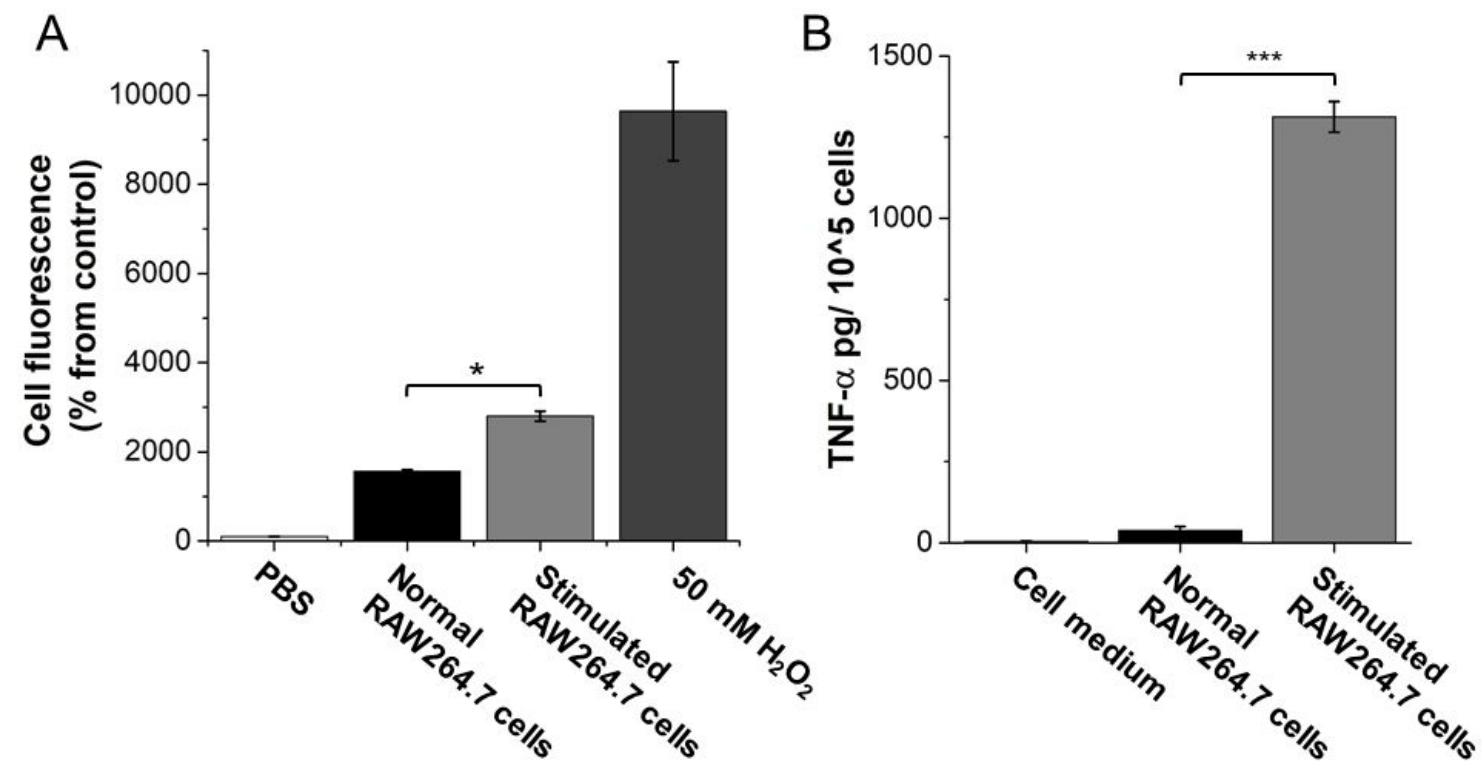

Figure S6. A) ROS quantification with $\mathrm{H}_{2}$ DCFDA fluorescence assay in macrophages with (grey) or without (black) inflammation stimulation. B) TNF- $\alpha$ release from macrophages determined using ELISA assay with (grey) or without (black) inflammatory stimulation; * and *** indicate a statistically significant difference at $p<0.05$ or $p<0.001$, respectively.

\section{References}

1 Iturmendi, A.; Theis, S.; Maderegger, D.; Monkowius, U.; Teasdale I. Coumarin-Caged Polyphosphazenes with a Visible-Light Driven On-Demand Degradation Macromol. Commun. 2018, 39 (18), 1800377.

2 Iturmendi, A.; Monkowius, U.; Teasdale, I. Oxidation Responsive Polymers with a Triggered Degradation via Arylboronate Self-Immolative Motifs on a Polyphosphazene Backbone ACS Macro Letters 2017, 6 (2), 150-154. 
Rothemund, S.; Aigner, T. B.; Iturmendi, A.; Rigau, M.; Husar, B.; Hildner, F.; Oberbauer, E.; Prambauer, M.; Olawale, G.; Forstner, R.; Liska, R.; Schroder, K. R.; Bruggemann, O.; Teasdale I. Degradable Glycine-Based Photo-Polymerizable Polyphosphazenes for Use as Scaffolds for Tissue Regeneration Macromol. Biosci. 2015, 15 (3), 351-363. 